\title{
Czynniki środowiskowe zwiększające ryzyko aktywacji i rozwoju chorób zapalnych jelit
}

\begin{abstract}
STRESZCZENIE
$\mathbf{N}$ ieswoiste zapalne choroby jelit (NChZJ) to szczególnie kłopotliwe schorzenia mające olbrzymi wpływ na przewód pokarmowy człowieka, a głównie jelito. Schorzenia te objawiają się przewlekłym niekontrolowanym stanem zapalnym jelit, trudnym do opanowania, przebiegającym z okresami występujących samoistnie zaostrzeń i remisji. W zależności od różnorodności występujących objawów oraz ich umiejscowienia w przewodzie pokarmowym człowieka choroby te mogą występować $w$ różnych postaciach. Najczęściej spotykane to: wrzodziejące zapalenie jelita grubego (WZJG) oraz choroba Leśniowskiego-Crohna (ChLC). Zasadnicza przyczyna aktywacji, jak również późniejszego rozwoju nie jest jasno zdefiniowana, wiadomo jednak że zaburzenia te mają podłoże autoimmunologiczne. Patogeneza NChZJ jest związana z przewlekłym, idiopatycznym, nawracającym stanem zapalnym przewodu pokarmowego. Narażenie na wiele czynników środowiskowych, które częściowo omówiono w poniższej pracy, szczególnie u osób genetycznie predysponowanych do rozwoju tych schorzeń, może aktywować przewlekły proces zapalny jelit.
\end{abstract}

\section{WPROWADZENIE}

Nieswoiste zapalne choroby jelit (NChZJ) to szczególnie kłopotliwe schorzenia przewodu pokarmowego. Najczęściej spotykane to: wrzodziejące zapalenie jelita grubego (WZJG) oraz choroba Leśniowskiego-Crohna (ChLC) (Tabela 1).

Wrzodziejące zapalenie jelita grubego jest przewlekłym procesem zapalnym błony śluzowej jelita grubego, głównie okrężnicy i odbytnicy. Etiologia schorzenia nie jest w pełni poznana. Wiadomo, że jest wieloczynnikowa. Zasadnicze znaczenie w patogenezie WZJG mają czynniki genetyczne, immunologiczne jak i środowiskowe. Choroba dotyczy wszystkich grup wiekowych, zarówno dzieci jak i osób starszych, jednak najczęściej jest diagnozowana w przedziale wiekowym 20-40 lat. Objawy chorobowe ulegają nasileniu pod wpływem cytokin prozapalnych, a występujące $\mathrm{w}$ tym schorzeniu zmiany mają charakter ciągły. Wśród objawów dominują biegunka z domieszką krwi i śluzu z uczuciem parcia na stolec oraz ból w jamie brzusznej. W zależności od nasilenia procesu zapalnego, w kale może być obecna również ropna wydzielina. Chorobie mogą towarzyszyć stany gorączkowe lub podgorączkowe oraz chudnięcie i ogólne osłabienie. Dominujące objawy są uzależnione od miejsca lokalizacji schorzenia. Mogą być one bardzo uciążliwe i szybko doprowadzić do utraty krwi oraz odwodnienia chorego. Gdy zajęciu procesem zapalnym ulega cała okrężnica, objawy WZJG przybierają charakter uogólniony. Schorzeniu dodatkowo mogą towarzyszyć dolegliwości pozajelitowe, skórne i stawowe.

Z kolei Choroba Leśniowskiego-Crohna może obejmować cały przewód pokarmowy, począwszy od jamy ustnej aż do odbytu. W odróżnieniu od WZJG, występujące tutaj zmiany mają charakter odcinkowy. Ten typ schorzenia najczęściej lokalizuje się w dolnej części przewodu pokarmowego, a zmiany w górnym segmencie rozpoznaje się jedynie $\mathrm{w}$ około $3 \%$ diagnozowanych przypadków. Poposiłkowy ból i uczucie pełności w jamie brzusznej, często zlokalizowany w okolicy prawego dołu biodrowego, wodno-śluzowa biegunka, wzdęcia, kolki, przelewanie treści jelitowej, zmiany około odbytnicze oraz aftowe zapalenie jamy ustnej są najczęściej zgłaszanymi objawami ChLC. Schorzenie to dotyka głównie ludzi młodych oraz w trzeciej i czwartej dekadzie życia. Zaburzenie homeostazy całego organizmu przez toczący się proces chorobowy jelit może wpłynąć dodatkowo na rozwój schorzeń sercowo-naczyniowych, neurologicznych, układu oddechowego lub wywołać stan zapalny stawów.

Etiologia nieswoistych zapalnych chorób jelit nie jest całkowicie zrozumiała. Wiadomo, że rozwijają się one częściej u osób z genetycznymi uwarunkowaniami, pod wpływem różnych czynników: środowiskowych, wirusowych lub bakteryjnych. Wykazano wzajemny związek między tymi czynnikami, a od- mgr inż. Jerzy Mrowicki*,

dr n. med. Małgorzata Mrowicka,

prof. dr hab. n. med. Ireneusz Majsterek

Zakład Chemii i Biochemii Klinicznej, Uniwersytet Medyczny w Łodzi, Narutowicza 60, Łódź 90-136

https://doi.org/10.18388/pb.2020_318

\autor korespondujący: jerzy.mrowicki@ umed.lodz.pl

Słowa kluczowe: choroby zapalne jelit, wrzodziejące zapalenie jelita grubego, choroba Leśniowskiego-Crohna, czynniki środowiskowe, komórki nabłonkowe jelit

Wykaz stosowanych skrótów: ChLC - choroba Leśniowskiego-Crohna; CMC - karboksymetyloceluloza (syn. Carmellosum); CRP - białko C-Reaktywne (ang. C Reactive Protein); DSS - siarczan dekstranu sodu; ESR - wskaźnik opadania erytrocytów (ang. erythrocyte sedimentation rate); IESC - komórki nabłonkowe jelit (ang. intestinal epithelial cells); NCS - niekaloryczne substancje słodzące; NChZJ - nieswoiste zapalne choroby jelit; NLPZ - niesteroidowe leki przeciwzapalne; OCP - dosutne środki antykonceptyjne (ang. oral contraceptive pills); P80 - polisorbat 80 (ang. polysorbate 80); PM - cząstki stałe (ang. particulate matter); PUFA - wielonienasycone kwasy tłuszczowe (ang. polyunsaturated fatty acids); ROS - reaktywne formy tlenu (ang. reactive oxygen species); SRB bakterie redukujące siarczyny (ang. sulphate-reducing bacteria); TNFa - czynnik martwicy nowotworów a (ang. tumor necrosis factor-a); UHT - bardzo wysoka temperatura (ang. ultra high temperature); VDR - receptor witaminy D (ang. vitamin D receptor); WZJG - wrzodziejące zapalenie jelita grubego

Praca ta została wsparta grantem nr 2016/23/B/NZ5/02630 z Polskiego Narodowego Centrum Nauki. 
Choroba może zaatakować każdy odcinek przewodu pokarmowego od jamy ustnej do odbytu, najczęściej dotyczy jelita krętego (końcowy odcinek jelita cienkiego) lub początkowej części jelita grubego, zmiany zapalne mają charakter odcinkowy.
Proces zapalny dotyczy głównie okrężnicy i odbytnicy, wyniszcza on głównie wewnętrzną część błony śluzowej nie przedostając się na zewnątrz jelita, występujące zmiany chorobowe mają formę ciągłą.
Uczucie pełności w jamie brzusznej oraz ból w trakcie lub po posiłku $\mathrm{z}$ częstą lokalizacją $\mathrm{w}$ okolicach prawego dołu biodrowego. Występujące objawy są uzależnione od miejsca lokalizacji zmian i ich rozległości, mogą różnić się intensywnością od łagodnych aż do ciężkich. Trwający przewlekle proces zapalny może doprowadzić do wystąpienia niedrożności jelit.
Początkowo dolegliwości bólowe o charakterze rozlanym potęgowane wzdęciami lub zlokalizowane $\mathrm{z}$ lewej strony nadbrzusza, często ustępujące po wypróżnieniu. Przewlekły stan zapalnym o różnym stopniu nasilenia,10-20\% przypadków ma przebieg ciężki z powikłaniami jelitowymi oraz pozajelitowymi.
Przelewanie treści jelitowej, nudności, wymioty, wzdęcia, kolki, biegunka wodno-śluzowa, z możliwą obecnością krwi, a dodatkowo zmiany w okolicach odbytu: szczeliny, ropnie, przetoki.
Ból w jamie brzusznej połączony z parciem na stolec, biegunka śluzowa z domieszką niemal zawsze świeżej krwi i/lub ropy, możliwe stolce bezkałowe. Często występuje niedokrwistość, przewlekłe zmęczenie, osłabienie, wymioty, obniżona odporność gorączka lub stany podgorączkowe. Podczas remisji u części chorych możliwe zaparcia.
U chorych skutkiem złego wchłaniania i biegunek może występować znaczna utrata wagi, braki mikro- i makroelementów z pożywienia, anemia, niedobór minerałów, witamin, utrata elektrolitów.
Utrata łaknienia, chudnięcie i niedożywienie rzadsze niż w ChLC. Na skutek dużej dobowej liczby wypróżnień często przekraczającej 20 może wystąpić odwodnienie, zaburzenia elektrolitowe.

Schorzeniu mogą towarzyszyć zmiany aftowe w jamie ustnej, stawowe, skórne, zapalnie spojówek, lęk, depresja.

Mogą współistnieć dolegliwości pozajelitowe, skórne, stawowe, stres.

powiedzią immunologiczną organizmu. Patogeneza tych schorzeń jest wieloczynnikowa, mogą być one zainicjowane działaniem bakterii, antygenów lub alergenów pokarmowych. Proces zapalny może zapoczątkować działanie białek roślinnych lub sztucznych dodatków do żywności, takich jak barwniki syntetyczne, substancje słodzące, konserwanty, a nawet obecność substancji chemicznych zawartych w napojach typu coca-cola lub gumie do żucia. Wśród innych czynników możemy wyróżnić gluten zawarty w zbożach, mleku UHT oraz drożdże. Obserwowano zależność między wykluczeniem z diety tych czynników, a wydłużeniem okresów remisji w ChLC. Bakteryjna flora jelitowa jest bardzo wrażliwa na nieodpowiednią dietę bogatą $\mathrm{w}$ wysokoprzetworzoną żywność, dodatkowo obfitującą w związki chemiczne oraz inne sztuczne dodatki w niej zawarte [1]. Naukowcy przeprowadzili badania kwestionujące identyfikację możliwych czynników środowiskowych, podczas których zaobserwowano zwiększoną zapadalność na NChZJ głównie wśród młodzieży [2]. Młodzi ludzie zwykle wykazują większą tendencję do spożywania przetworzonej żywności, a ich dieta często obfituje $\mathrm{w}$ wysokokaloryczne produkty typu fast food, co może częściowo tłumaczyć rosnącą liczbę przypadków w tej grupie wiekowej. Badania dotyczące oceny wpływu narażenia na środowiskowe czynniki ryzyka obejmujące 5 różnych grup środowiskowych potwierdziły ścisły ich związek z powstawaniem omawianych schorzeń u dzieci. Potwierdza to również wzrost zachorowalności w krajach wysoko rozwiniętych [3]. Ponadto, do zaostrzenia objawów przyczyniało się palenie papierosów lub bierne narażenie na dym tytoniowy oraz niskie poziomy witaminy D. Zaburzenia snu były częstym objawem zgłaszanym przez pacjentów z NChZJ [4]. Ryzyko zachorowania dodatkowo rosło u osób obciążonych genetycznie u których nieodpowiednie nawyki żywieniowe w dużej mierze decydowały o szybkim rozwoju schorzenia.

Ze względu na dowiedzione duże znaczenie diety w rozwoju nieswoistych zapalnych chorób jelit oraz wyjątkową uciążliwość występujących objawów, znacznie pogarszających komfort życia pacjenta, w niniejszej pracy podjęto próbę podsumowania znanych czynników środowiskowych mogących wpływać na aktywację omawianych postaci NChZJ. Temat jest istotny także ze względu na stale rosnącą liczbą zachorowań na całym świecie.

\section{WPŁYW DIETY I SKŁADNIKÓW ŻYWNOŚCI NA ROZWÓJ NIESWOISTYCH ZAPALNYCH CHORÓB JELIT}

Zwiększona częstość występowania nieswoistych zapalnych chorób jelit koreluje się z powszechną westernizacją diety: wysokim spożyciem białka, czerwonego mięsa, tłuszczu oraz cukru, przy jednoczesnej niskiej obecności błonnika pokarmowego pochodzącego z owoców i warzyw. Wykazano, że rodzaj spożywanego pokarmu przyczynia się do zmian w mikrobiomie jelitowym, który może oddziaływać prozapalnie i poprzedzać rozwój NChZJ, szczególnie u osób podatnych [5]. Codzienne spożycie nadmiernej ilości cukru przy niewielkiej ilości błonnika pokarmowego łączono z częstym występowaniem NChZJ [6-9]. Wszechobecny niezdrowy tłuszcz znajduje się m.in. w produktach typu fast food i twardych margarynach oraz produktach wytworzonych $\mathrm{z}$ ich udziałem. Utwardzone tłuszcze za- 
wierają wysoce toksyczne izomery trans, powstające podczas uwodornienia olejów roślinnych, które mogą znacznie zwiększać ryzyko także innych chorób. Izomery trans są przyczyną nadwagi oraz znajdują się na czele czynników zwiększających ryzyko choroby niedokrwiennej serca w znacznie większym stopniu niż tłuszcze nasycone. Wykazano, że nasycone kwasy tłuszczowe odgrywają istotną rolę w zapaleniu poprzez modulowanie mikrobiomu jelitowego i receptorów błonowych w makrofagach [10-11]. Wyniki badań wskazują, że wysokie spożycie wielonienasyconych kwasów tłuszczowych n-6 (ang. polyunsaturated fatty acids, PUFA) i kwasu arachidonowego przy jednoczesnym niskim spożyciu wielonienasyconych n-3 PUFA zwiększało ryzyko zapadalności na NChZJ. Zaobserwowano także związek między stosowaniem dużych ilości wszystkich tłuszczów a zwiększoną wykrywalnością ChLC i WZJG [12]. Okazało się, że prostaglandyny i leukotrieny powstałe z kwasu arachidonowego uczestniczą $w$ reakcjach zapalnych. W innych badaniach, które potwierdziły znaczenie opisanych czynników ryzyka, obserwowano dodatkowo dodatnią zależność między nadmiernym spożyciem kwasu linolowego a NChZJ.

\section{ODMIENNA ROLA BŁONNIKA W CHLC I WZIG}

Rolę ochronną w przypadku podatności na NChZJ przypisano wysokiemu spożyciu błonnika rozpuszczalnego $\mathrm{z}$ owoców cytrusowych i warzyw. Błonnik pokarmowy w diecie pełni rolę prebiotyku, ma on fundamentalne znaczenie dla prawidłowego funkcjonowaniu układu pokarmowego, chroni ludzkie ciało przed rozwojem raka jelita grubego, przyczyniając się do zmniejszenia stanu zapalnego. Badania wykazały, że przyjmowanie błonnika wiązało się z wolniejszym postępem ChLC, ale nie wpływało na WZJG [13]. Podczas zaostrzenia choroby zalecano ograniczenie spożycia błonnika, a $\mathrm{w}$ trakcie remisji chorzy powinni również unikać alkoholu oraz związków siarki obecnych w wielu produktach spożywczych [14]. Błonnik jest fermentowany przez szczepy Bifidobacteria obecne w jelitach, na skutek czego powstają krótkołańcuchowe kwasy tłuszczowe, będące ważnym źródłem energii dla komórek błony śluzowej jelita [15]. Błonnik występuje w postaci rozpuszczalnej i nierozpuszczalnej w wodzie. Frakcja nierozpuszczalna podczas wykonywania funkcji mechanicznej w przewodzie pokarmowym może wywierać drażniący wpływ na ścianę jelita nasilając objawy zapalenia. W warunkach prawidłowych frakcja ta stymuluje perystaltykę, a tym samym skraca czas tranzytu jelitowego. Błonnik rozpuszczalny tworzą głównie pektyny i gumy, a ich źródłem mogą być poddane obróbce cieplnej celem ułatwienia trawienia owoce i warzywa. Po uwodnieniu powstały w jelitach żel, znacznie poprawia funkcjonowanie przewodu pokarmowego, obniżając jednocześnie poziom cukru i cholesterolu we krwi. Frakcja ta ma olbrzymie znaczenie dla bakterii tworzących mikroflorę jelitową, sprzyjając namnażaniu korzystnej flory przez co wpływa na różnicowanie i proliferację komórek nabłonkowych jelit [16]. W badaniach wykazano, że niedobory maślanu, wywołane pośrednio brakiem rozpuszczalnego błonnika, mogą przyczyniać się do uszkodzenia błony śluzowej jelit, a tym samym łatwiejszego przenikania toksycznych związków do organizmu, które z kolei mogą indukować przewlekły procesu zapalny w jelitach [17]. Rozpuszczalne włókno spełnia wiele ważnych zadań, jest pokarmem dla bakterii zamieszkujących jelito grube, a pod wpływem wydzielanych przez nie enzymów rozkłada się. Nie powoduje podrażnienia mechanicznego jego ścian, a jedynie przechodzi przez jelito_spowalniając jelitowy transport i zmiękczając stolec. Dodatkowo, wydłużony okres obecności składników odżywczych dostarczanych z pokarmami bogatymi w błonnik rozpuszczalny i potas ma pozytywny wpływ na leczenie biegunki, często występującej w przebiegu omawianych schorzeń. Ten rodzaj błonnika zwiększa też objętość wydalanych odchodów, rozpuszczając się i pęczniejąc w świetle jelita pod wpływem wchłoniętej wody. Ponadto, włókno to ma zdolność wiązania kwasów żółciowych, zmniejsza wchłanianie tłuszczu, a także ma zdolność usuwania związków rakotwórczych z jelita oraz toksycznych jonów metali ciężkich, zapobiegając w ten sposób ich wchłanianiu do krwi lub limfy.

\section{ROLA MLEKA I JEGO PRZETWORÓW W NCHZJ}

$\mathrm{W}$ badaniach prowadzonych $\mathrm{w}$ kierunku roli mleka $\mathrm{w}$ diecie wykazano, że zaburza ono równowage bakterii jelitowych. Szczególnie mleko poddane obróbce w bardzo wysokiej temperaturze (ang. ultra high temperature, UHT) jest pozbawione flory bakteryjnej, co sprzyja rozwojowi patologicznej mikroflory w przewodzie pokarmowym. Enzym laktaza jest wytwarzany w jelicie cienkim tylko części ludzi, u pozostałych osób jego produkcja zanika już w dzieciństwie. Dodatkowo, u pacjentów z NChZJ z powodu uszkodzenia jelit i ich nadmiernej przepuszczalności może rozwinąć się nietolerancja laktozy, objawiająca się wzdęciami i biegunką. U znacznej części osób z tymi chorobami obserwowano ostre objawy po spożyciu produktów mlecznych, a badania potwierdziły ich silny związek z nasileniem choroby [18].

\section{OCHRONNA ROLA WITAMINY D}

Witamina D pełni istotną funkcję w procesie wchłaniania wapnia do kości, a także jest ważnym czynnikiem dla prawidłowego funkcjonowania układu odpornościowego. Ze względu na małą liczbę słonecznych dni w roku, a także poprzez stosowanie filtrów przeciwsłonecznych w lecie, niedobory witaminy $\mathrm{D}$ u ludzi są nagminne. W grupie chorych na NChZJ bardzo często występują jej braki oraz obniżona ekspresja receptora witaminy D (ang. vitamin $D$ receptor, VDR). Prowadzone badania u osób z omawianymi chorobami pochodzącymi z południowo-wschodnich i zachodnich rejonów Norwegii wykazały, że niedobór witaminy $\mathrm{D}$ był $\mathrm{u}$ nich bardzo powszechny, a u pacjentów dotkniętych ChLC przejawiało się to częstszymi atakami i wyższą aktywnością zapalną tego schorzenia [19]. Wykazano, że witamina D wpływa na ekspresję genu NOD2, a jej brak powoduje upośledzenie integralności nabłonka jelit, co przekłada się na większy stan zapalny [20]. Nadmierna apoptoza komórek nabłonkowych jelit (ang. intestinal epithelial cells, IECS) może być częściowo odpowiedzialna za stan zapalny i późniejszy rozwój schorzenia. Badania wykazały, że witamina D blokuje rozwój zapalenia jelita grubego poprzez hamowanie apoptozy IECS [21]. W tkankach pobranych podczas biopsji z jelit chorych obserwowano, że wraz ze wzrostem penetracji komórek odpornościowych oraz zwiększonym poziomem czynnika martwicy nowotworów 
a (ang. tumor necrosis factor-a, TNF-a) i mikro RNA miR346 następowało zmniejszenie ilości naskórkowego receptora VDR. Również w eksperymentalnie indukowanym modelu zapalenia mysiego jelita grubego, ekspresja VDR zmniejszała się wraz z postępem procesu zapalnego i była odwrotnie skorelowana z indukcją TNF-a i miR-346 w błonie śluzowej jelita. Wykazano, że podczas zapalenia błony śluzowej TNF-a indukuje podwyższoną ekspresję miR-346, co prowadzi do zmian naskórkowego VDR. Z kolei zmniejszenie ilości śluzówkowego receptora VDR wpływa na pogorszenie integralności bariery nabłonkowej błony śluzowej i nasilenie procesu zapalnego jelita grubego [22]. Suplementacja witaminy D miała korzystny wpływ na zmniejszenie objawów chorobowych pacjentów z WZJG, obserwowano zmniejszenie tempa sedymentacji erytrocytów (ang. erythrocyte sedimentation rate, ESR) oraz markera stanów zapalnych i reumatologicznych (ang. C Reactive Protein, CRP), a także zwiększenie poziomu ekspresji genu katelicydyny LL37 [23].

\section{ZNACZENIE DIETY ELIMINACYJNEJ I ŻYWIENIA DOJELITOWEGO}

Najnowsze badania wykazały, że wyłączne żywienie dojelitowe pozostaje najskuteczniejszą metodą wywołania remisji w aktywnej chorobie Crohna. Badania pokazują, że może być ono skuteczne nawet w zamykaniu przetok jelitowo-skórnych w ciężkiej postaci ChLC [24]. Ponadto wykazano zależność między modyfikacją diety polegającą na kilkutygodniowej fazie eliminacji niektórych pokarmów, po której następowała faza podtrzymująca, a poprawą jakości życia związaną z większą częstością remisji w NChZJ. Dieta ma istotne znaczenie dla aktywacji omawianych schorzeń, ale pełni też istotną rolę w rozwoju zapalenia podczas trwania choroby. Modyfikacja diety może poprawić biochemiczne markery stanu zapalnego oraz indukować gojenie błony śluzowej [24]. Badania wskazują, że częściowe żywienie dojelitowe uzupełnione dietami eliminującymi może działać korzystnie w leczeniu zarówno WZJG jak i ChLC. Stosowana dieta eliminująca zboża, cukier, produkty mleczne $\mathrm{u}$ chorych dzieci znacznie poprawia biomarkery laboratoryjne i ich wyniki kliniczne [25-27]. Inna strategia polega na rezygnacji z pokarmów działających jako antygeny, mogących powodować dysbiozę w przewodzie pokarmowym i zapoczątkować zapalenie błony śluzowej [28]. Stopniowe wykluczenie roślin strączkowych, nabiału, jaj, nasion, orzechów, olejów rafinowanych i produktów zawierających sztuczne dodatki oraz używek takich jak kawa czy alkohol, może przekładać się na powolną poprawę stanu zdrowia. Korzystne efekty przynosiło zastąpienie wymienionych produktów przez świeżo sporządzone pokarmy o wysokiej wartości odżywczej, spożycie probiotyków i żywności fermentowanej, przy jednoczesnej aktywność fizycznej, eliminacji stresu oraz odpowiedniej długość snu [29]. Ze względu na to że, ogólnoustrojowe zapalenie powoduje wzrost zapotrzebowania na białko, celem uzupełnienia niedoborów zaleca się m.in. przygotowywanie zup na bazie bulionu kostnego. Dieta wykluczająca przy ChLC eliminuje produkty, które mogą zmienić funkcję bariery powodującej dysbiozę oraz mogą wpłynąć na czynniki bakteryjne i wirusowe, umożliwiając translokację bakteryjną, przemieszczanie bakterii przez nabłonek śluzówki jelita do krążenia wrotnego. Zapalne produkty mogące zmienić przepuszczalność jelitową, które zaleca się wyeliminować z diety to pszenica, nabiał, emulgatory, maltodekstryny, karageniny i siarczyny [24]. Stosowanie proponowanych diet $\mathrm{u}$ chorych może zwiększać niedobory mikroskładników odżywczych, dlatego nie może trwać zbyt długo. Dieta powinna być przygotowana indywidualnie dla pacjenta przez dietetyka, musi być bogata w składniki odżywcze pochodzące ze świeżej, nie przetworzonej żywności, uwzględniając uzupełnienie ewentualnych braków. Produkty zalecane i niezalecane przy NChZJ przedstawia Tabela 2.

\section{NIEDOBORY ŻYWIENIOWE A NCHZJ}

Wykazano że, niedobory niektórych mikroelementów mogą wpływać na przebieg nieswoistych zapalnych chorób jelit, zwiększając występowanie powikłań pogorszających jakość życia pacjentów [30]. Niedobory mogą być efektem niewystarczającego spożycia składników odżywczych ze względu na wykluczenia różnych grup żywności, jak również upośledzonego przyswajania. U osób z NChZJ niedobory mikroelementów dotyczą najczęściej żelaza, witamin D i B12 oraz cynku, który zwiększa zapalenie jelit poprzez aktywację makrofagów [31]. Niedobory witaminy A, potasu, wapnia, miedzi, selenu i kwasu foliowego są rzadziej spotykane. Osoby z ChLC, jak również z celiakią, a także z wrzodem żołądka lub dwunastnicy, są szczególnie narażone na hipokalcemię. Pojawia się ona wówczas gdy wapń

Tabela 2. Zalecenia dietetyczne w NChZJ

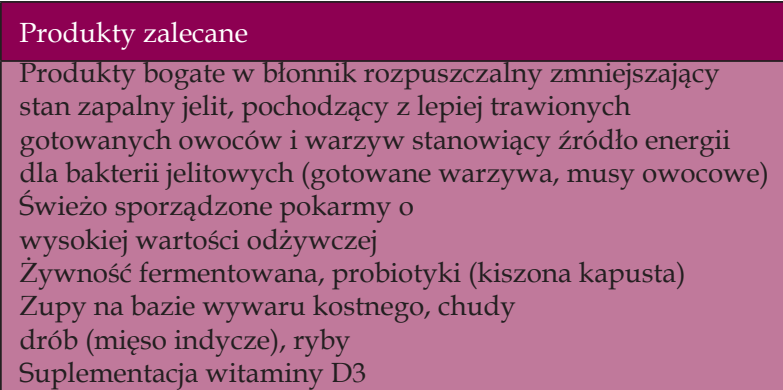

Produkty niezalecane

Produkty zawierające błonnik nierozpuszczalny mogący podrażniać ściany jelita (zboża z pełnego przemiału, rośliny oleiste - nasiona i orzechy, rośliny strączkowe) Gluten zawarty w zbożach (pszenica, jęczmień, owies, orkisz) Drożdże Mleko i wszystkie produkty z mleka zwierzęcego Czerwone mięso Produkty smażone na głębokim tłuszczu Tłuszcze uwodornione (żywność wysokoprzetworzona typu fast-food), tłuszcze nasycone, rafinowane oleje roślinne oraz wszystkie produkty wytworzone z ich udziałem Cukier rafinowany i sztuczne substancje słodzące Żywność wytworzona z udziałem emulgatorów Białka roślinne i syntetyczne barwniki, substancje konserwujące zawarte w żywności (siarczyny) Ostre przyprawy Używki: alkohol, kawa 
jest źle wchłaniany z przewodu pokarmowego. Choroby dwunastnicy i dalszej części jelita cienkiego mogą znacznie zmniejszyć jego wchłanianie, ponieważ odbywa się ono właśnie w tych częściach układu pokarmowego. Wśród innych przyczyn hipokalcemii wymienia się niedobory witaminy D i magnezu, diagnozowane z dużą częstością u osób z NChZJ. Zaleca się możliwie najszybsze uzupełnienie istniejących u pacjenta braków, ponieważ w ich wyniku mogą występować efekty uboczne: zmiany neurologiczne, opóźniony wzrost, niedokrwistość, skurcze mięśni i zmęczenie. Badania prowadzone wśród dzieci ze schorzeniami jelit wykazały nieprawidłowości w poziomach pierwiastków śladowych, które mogą wynikać z ich niewystarczającego spożycia, ale również z powodu zwiększonych strat wynikających z upośledzonego wchłaniania jelitowego związanego $z$ toczącym się procesem zapalnym. Proces ten może przebiegać w wyniku zmniejszenia wymiatania wolnych rodników przez niedobór cynku i selenu, dlatego zaleca się uzupełnienie tych pierwiastków śladowych [32].

\section{ROLA DODATKOWYCH SUBSTANCJI ZAWARTYCH W ŻYWNOŚCI}

\section{Znaczenie dwutlenku siarki i żelaza}

Dwutlenek siarki to medium szeroko stosowane do konserwowania, między innymi suszonych owoców, moszczu, pulpy owocowej, chrzanu oraz niektórych soków warzywnych i owocowych jak również lodów. Siarczyny są obecne we wszystkich winach owocowych. Wykazano, że dwutlenek siarki jest szkodliwy nie tylko dla układu oddechowego, ale także dla żołądka i jelit ssaków [33]. Spożycie żywności o wysokiej zawartości siarki, takich jak pirosiarczyn, dwutlenek siarki, przyczynia się do szybkiego rozwoju bakterii redukujących siarczyny (ang. sulphate-reducing bacteria, SRB). Bakterie SRB znaleziono w 98\% próbek kału pochodzącego od pacjentów z WZJG. Namnażanie SRB następuje również po spożyciu wysokoprzetworzonej żywności z użyciem emulgatorów, sztucznych barwników oraz konserwantów. Wynika to także z obecności w jelicie mucynowo-siarkowego cukru wielosiarkowego. Podczas wzrostu tych bakterii siarka jest wykorzystywana do tworzenia mostków w śluzie jelitowym. Merkaptoidy powstałe podczas redukcji siarczynów wraz z siarczkami wpływają na utlenianie kwasów tłuszczowych w kolonocytach. Wytwarzany w tym czasie n-maślan pełni funkcję ochronną komórek nabłonkowych przed działaniem szkodliwych czynników. Wykazano że, bakterie redukujące siarczyny biorą udział w etiologii WZJG, przyczyniając się do powstania nieprawidłowego śluzu jelitowego poprzez wytwarzanie wysoce toksycznego siarkowodoru, który uszkadza nabłonek jelitowy [1].

Kolejnym mediatorem prooksydacyjnym wpływającym na zapalenie jelit i mechanizmy stresu komórkowego jest żelazo [34]. Wpływ wysokiego poziomu hemu na skład mikrobiomu jest znaczący szczególnie w przewlekłym zapaleniu, jakie występuje w przebiegu NChZJ. Przyczynia się on do powstania dysbiozy jelitowej. $\mathrm{W}$ badaniach na myszach wykazano, że zmiany w mikroflorze jelitowej wywołane przez hem były podobne do sztucznie indukowanych siarczanem dekstranu sodu (DSS), obserwowano również zmniejszenie poziomu maślanu w kale na skutek wzrostu ilości hemu w pożywieniu [35].

\section{Działanie sztucznych substancji słodzących}

Niskokaloryczną substancją poprawiającą smak i zapach produktów wykorzystywaną do słodzenia napojów, ciast jak również gum do żucia jest sacharyna. W badaniach wykazano jej hamujące działanie na wzrost komensalnych bakterii jelitowych, jak też jej związek ze wzrostem ryzyka rozwoju nowotworów różnego typu. Sacharyna może mieć działanie prozapalne, wskazywana jest kluczowym czynnikiem dla aktywacji i rozwoju NChZJ. Przyczynia się ona do powstawania zaburzeń $w$ inaktywacji proteaz trawiennych, wpływa na trawienie warstwy śluzowej i przełamuje barierę jelitową. Sukraloza ma podobny mechanizm działania [36]. Zaobserwowano też, że spożycie niekalorycznych substancji słodzących (NCS): ksylitolu, erytrytolu, sukralozy, aspartamu, acesulfamu K i sacharyny może modyfikować skład mikroflory oraz zwiększać wydzielanie hormonów żołądkowo-jelitowych, które regulują ruchliwość jelit [37]. Potencjalny wpływ sztucznych substancji słodzących na rozwój WZJG i ChLC potwierdzono również w innych badaniach [38].

Szkodliwy wpływ zastosowanych emulgatorów

Rosnącą zapadalność na ChLC wiąże się z użyciem emulgatorów w żywności i napojach. Badania przeprowadzone na modelach zwierzęcych wykazały, że emulgatory takie jak karagenina i karboksymetyloceluloza, powodują owrzodzenie jelit o cechach histopatologicznych podobnych do rozpoznawanych w NChZJ. Poprzez przełamanie bariery nabłonkowej i zakłócenie wrodzonej odpowiedzi błony śluzowej na mikroorganizmy oraz stymulowanie cytokin prozapalnych, emulgatory te mogą wpływać na rozwój NChZJ [39]. Inni badacze potwierdzają, że syntetyczne emulgatory dietetyczne zawarte w produktach spożywczych takie jak karboksymetyloceluloza (CMC) i polisorbat 80 (P80) powodują zaburzenia zapalne zmieniając jednocześnie skład mikroflory jelitowej. Wykazano że, dysbioza wynikająca z ich działania może być czynnikiem decydującym o rozwoju raka okrężnicy [40]. Związek między stosowaniem emulgatorów w przetworzonej żywności, a wzrostem ryzyka NChZJ w modelu zwierzęcym potwierdzają też inne badania [41]. Stan zapalny wywołany działaniem P80 i CMC jest związany z erozją warstwy śluzowej na skutek zmian w mikroflorze w kierunku bakterii prozapalnych. Wpływa on na zmniejszenie poziomu krótkołańcuchowych kwasów tłuszczowych, kwasów żółciowych oraz wzrost poziomu w kale lipopolisacharydu i flageliny. Podobnie karagenina może wywoływać stan zapalny jelita grubego poprzez zmniejszoną liczebność bakterii przeciwzapalnych, agregację monocytów i ekspresję czynnika martwicy nowotworów TNF-a [42]. Zakłada się, że defekty bariery śluzówkowej u pacjentów z chorobami jelit występują również na skutek stosowania detergentów w gospodarstwach domowych [43]. Emulgatory wpływają na uszkodzenia ochronnej błony śluzowej jelit, przyczyniając się do powstania ich stanu zapalnego poprzez bezpośredni kontakt bakterii z nabłonkiem jelitowym. Zmieniony skład mikroflory $\mathrm{w}$ kierunku powstawania bakterii o właściwościach prozapalnych, przyspiesza rozpad warstwy ochronnej śluzu pogłębiając drażnienie jelit co przekłada się na nieprawidłowe funkcjonowanie układu odpornościowego. Emulgatory te oprócz 
przetworzonej żywności są również szeroko stosowane przy produkcji części leków.

\section{WPEYW STOSOWANYCH LEKÓW NA ROZWÓJ NIESWOISTYCH ZAPALNYCH CHORÓB JELIT}

$\mathrm{W}$ prowadzonych $\mathrm{w}$ tym kierunku badaniach potwierdzono zależność między narażeniem na antybiotyki w dzieciństwie, które zakłócały prawidłową tolerancję mikroflory jelitowej, a późniejszym rozwojem NChZJ [44]. Większe ryzyko tych schorzeń wiązało się także ze stosowaniem niesteroidowych leków przeciwzapalnych (NLPZ) oraz doustnych środków antykoncepcyjnych (ang. oral contraceptive pills, OCP), na skutek naruszenia bariery jelitowej przez antygeny i zmiany w mikroflorze [45-46]. Wykazano że, stosowanie hormonalnych środków antykoncepcyjnych wiązało się z ryzykiem ChLC, jednak związek z WZJG dotyczył tylko kobiet z historią palenia papierosów [47]. Zależność tę potwierdzają również inne badania [48-49].

\section{ROLA PALENIA PAPIEROSÓW ORAZ STRESU PSYCHICZNEGO}

Ryzyko zachorowania na NChZJ może znacznie wzrosnąć wskutek narażenia wszystkich członków rodziny na podobne zagrożenia [50]. Jednym z nich może być palenie papierosów lub bierna codzienna ekspozycja na dym tytoniowy. Przeprowadzone badania kohortowe wykazały zwiększone ryzyko ChLC u palaczy i osób które rzuciły palenie. Ryzyko WZJG rosło w ciągu 2-5 lat od zakończenia uzależnienia [51]. Palenie jest czynnikiem ochronnym dla wrzodziejącego zapalenia jelita grubego, ale ryzyka dla choroby Leśniowskiego-Crohna. Stąd zaprzestanie palenia jest podstawową strategią terapeutyczną dla pacjentów z ChLC [52-53]. Wykazano, że narażenie na dym papierosowy przez dzieci często wiązało się z koniecznością późniejszego przeprowadzenia operacji w ChLC, ryzyko operacji zmniejszało karmienie piersią w dzieciństwie [54].

Wykazano że, stres psychiczny wpływa na zaburzenie homeostazy jelitowej poprzez zmianę działania osi mózgowo-jelitowej i może mieć krótko- lub długoterminowy wpływ na funkcje układu trawiennego, u chorych może wywołać nawrót lub zaostrzenie objawów NChZJ [55]. Współistnienie otyłości jest dodatkowo związane z większym odczuwaniem bólu, zmęczenia oraz depresją i lękiem [56].

\section{WPŁYW ZANIECZYSZCZENIA POWIETRZA I OBECNOŚCI METALI CIEZŻKICH NA MIKROBIOM JELITOWY}

Kolejnym czynnikiem środowiskowym wpływającym na wzrost ryzyka zachorowania na NCHZJ jest zanieczyszczone powietrze [57]. Ma ono bezpośredni wpływ na komórki nabłonkowe jelit, pojawienie się ogólnoustrojowego stanu zapalnego i aktywację układu odpornościowego. Wpływ tych zanieczyszczeń na jelito występuje podczas oczyszczania limfatycznego śluzowo-rzęskowego (ang. particulate matter, PM), a ich źródłem może być również żywność i woda. Na skutek tego dochodzi do zmian w składzie mikroflory jelitowej [58]. Cząstki stałe lub inne składniki obecne w powietrzu mogą przyczyniać się do obrony śluzówkowej gospodarza i wywoływać reakcje immunologiczne [59]. Wykazano, że stałe cząstki wprowadzone z pożywienia mogą wyzwalać i przyspieszać rozwój NChZJ, szczególnie u osób z predyspozycją. Ich penetracja może wystąpić w wyniku połączenia kilku czynników, w tym zwiększonej przepuszczalności jelit, klirensu, zmniejszonej ruchliwości okrężnicy oraz zmienionej funkcji metabolicznej i składu mikroflory jelitowej [60]. Podczas wdychania zanieczyszczeń gazowych jelita są narażone na zanieczyszczone powietrze. W trakcie prowadzonych badań zaobserwowano, że młodzi ludzie mieszkający na obszarach o wysokim stężeniu dwutlenku siarki wykazywali zwiększoną tendencję do rozwoju WZJG, a mieszkańcy obszarów o wysokim poziomie dwutlenku azotu byli bardziej narażeni na rozwój ChLC. Metale ciężkie są również związkami środowiskowymi, które mogą przyczyniać się do rozwoju NChZJ. Ze względu na zanieczyszczenie środowiska są one szeroko obecne w wielu produktach spożywczych. Największe ich nagromadzenie znajduje się w owocach morza, rybach, ryżu oraz surowcach warzywnych tj. sałaty, rzodkiewki, buraki, szpinak, pietruszka, marchew. Obecność metali ciężkich wiąże się z szerokim zakresem efektów toksycznych, w tym rakotwórczości, stresu oksydacyjnego, uszkodzenia DNA oraz wpływu na układ odpornościowy. Zatopiona rtęć powoduje różne zaburzenia w jelitach. Może występować ból brzucha, wrzody i krwawa biegunka [61]. Wykazano, że narażenie na metale ciężkie może prowadzić do dysbiozy mikroflory jelitowej [62]. Zaobserwowano, że długotrwałe narażenie na środowisko zanieczyszczone metalami ciężkimi powodowało statystycznie istotną różnicę w składzie mikroflory jelitowej, zarówno na poziomie rodzaju, jak i ilości bakterii. U zwierząt w obszarze zanieczyszczonym metalami ciężkimi zaobserwowano dużą liczbę Parabacteroides, Rikenella i chorobotwórczego Desulfovibrio, Bilophila. Zmiana dominujących gatunków bakterii dotyczyła zmniejszenia liczby i różnorodności szeregu ochronnych beztlenowców komensalnych wraz ze starzeniem się ludzkiego ciała. Wyniki uzyskane podczas badań pokazują, że ilość Bakteroides znacznie wzrosła pod wpływem metali ciężkich, podczas gdy udział mikroorganizmów z genomu Firmicutes był zmniejszony. Stosunek liczby Firmicutes/Bacteroides jest wiarygodnym wyznacznikiem stanu mikroorganizmów jelitowych człowieka. Toksyczność metali ciężkich dla organizmów jest w dużej mierze utożsamiana ze stresem oksydacyjnym, a spadek liczby probiotyków może nasilać efekty jego działania. Obecne badania na ropuchach wykazały, że zanieczyszczenie metalami ciężkimi szkodzi populacji probiotyków i powoduje znaczne zmniejszenie zarówno Lactobacillus jak i Bifidobacterium, który jest najbardziej wrażliwy na toksyczność metali ciężkich niż Lactobacillus. Wynik ten potwierdzono $\mathrm{u}$ myszy narażonych na kadm. Zanieczyszczenie tymi metalami wpłynęło również na różnorodność gatunkową mikroflory przewodu pokarmowego, hamując wzrost niektórych szczepów flory jelitowej [63]. Badanie epidemiologiczne wykazało silny pozytywny związek między poziomem ołowiu w kości a otyłością u dzieci, która może utrzymywać się $\mathrm{w}$ wieku dorosłym. Zmieniona mikroflora jelitowa jest silnie związana ze wzrostem masy ciała, co może oznaczać, że ekspozycja na ołów (Pb) jest bezpośrednim czynnikiem zmieniającym mikroflorę jelitową. Obserwowano okołoporodową ekspozycja na ołów w populacji myszy. Pomimo jej 
zaprzestania w wieku 3 tygodni, trwale zmieniła ona mikroflorę jelitową i była istotnie związana ze wzrostem masy ciała u dorosłych myszy w wieku około 40 tygodni. Całkowita liczba bakterii tlenowych i beztlenowych różniła się znacznie w zależności od grupy. Bakterie z rodzaju Pseudomonas, Enterobacter i Desulfovibrio miały większą liczebność u dorosłych myszy narażonych okołoporodowo na $\mathrm{Pb}$ niż w grupie kontrolnej. Różnorodność mikroflory jelitowej w grupie badanej została zakłócona i nie była tak odporna jak w grupie kontrolnej. Mikroflora jelitowa jest ważna w utrzymaniu zdrowia ludzi, w tym w określaniu masy ciała. Otyli ludzie prawdopodobnie mają mniejszy udział Bacteroides niż Firmicutes, zmieniona liczba pokazuje zwiększoną zdolność do czerpania energii z diety, podczas gdy stosunek Bacteroide/Firmicutes wzrasta wraz ze spadkiem masy tłuszczu. Zaobserwowano również, że 2 szczepy Akkermansia i Desulfovibrio związane ze zdrowiem były istotnie skorelowane z narażeniem na ołów. Akkermansja została całkowicie zniesiona $\mathrm{w}$ grupie poddanej ekspozycji, podczas gdy liczba Desulfovibrio wzrosła. Wykazano również częściowe działanie ochronne Akkermansji na otyłość i stany zapalne [64]. Dowiedziono, że otyłość zwiększa ryzyko nawrotu NChZJ, modyfikuje niekorzystnie farmakokinetykę czynników biologicznych oraz jest związana z wyższym ryzykiem niepowodzenia leczenia [56]. Podsumowując dane ekologiczne, wykazano dodatnią korelację między poziomem zanieczyszczenia powietrza, a hospitalizacją związaną ze schorzeniami zapalnymi jelit [65]. W badaniach przeprowadzonych u osób z NChZJ zaobserwowano zmniejszoną liczbę bakterii Firmicutes i wzrost liczby Proteobacteria. Obiecujące wyniki w leczeniu tych chorób daje korekcja dysbiozy poprzez zastosowanie terapii przeszczepu kału, przeszczepu flory bakteryjnej wraz z zastosowaniem probiotyków [66].

\section{PODSUMOWANIE}

W niniejszym zestawieniu pracy opartym na przeglądzie dostępnej w tej dziedzinie literatury wykazano, że niewłaściwa dieta i obecność substancji dodatkowych w przetworzonej żywności mogą zwiększać ryzyko wystąpienia NChZJ. Nadmierne spożycie białka, tłuszczów nasyconych, białego cukru, przy jednoczesnej niskiej podaży błonnika, a przede wszystkim jego frakcji rozpuszczalnej może inicjować proces zapalny, szczególnie u osób z genetyczną skłonnością do tych chorób. Podobny efekt wykazano w przypadku sztucznych dodatków do żywności, syntetycznych barwników, substancji słodzących, konserwantów i całej gamy dodatków chemicznych znajdujących się w żywności, w tym m.in. dodatku dwutlenku siarki, słodzików oraz glutenu obecnego w zbożach. Obserwowano również niekorzystny wpływ mleka, a szczególnie poddanego obróbce termicznej UHT, które dodatkowo narusza równowage bakterii jelitowych. Zanieczyszczenia obecne w powietrzu mają bezpośredni wpływ na komórki nabłonkowe jelit i pojawienie się ogólnoustrojowego stanu zapalnego. Narażenie na metale ciężkie przyczynia się do powstania dysbiozy mikroflory jelitowej, a brak homeostazy przekłada się na zwiększoną podatność na patogeny. Stwierdzono dodatnią korelację między aktywacją NChZJ a zanieczyszczonym powietrzem. Palenie papierosów jest czynnikiem ryzyka rozwoju ChLC, ochronnym przed wystąpieniem WZJG. W niniejszej pracy wykazano również, że emulgatory, takie jak karagen, karboksymetyloceluloza, polisorbat 80 oraz stosowane detergenty domowe wykazują działanie prozapalne, zmieniając skład mikroflory jelitowej, a tym samym zwiększają ryzyko aktywacji omawianych chorób. Ryzyko rozwoju NChZJ rosło również w przypadku niedoborów żywieniowych i braku mikroelementów oraz witamin, głównie witaminy D3. Pod wpływem wyżej wspomnianych czynników środowiskowych, szczególnie u osób genetycznie obciążonych rodzinną predyspozycją do występowania tych schorzeń, następowała nadprodukcja cytokin prozapalnych i zaburzenie homeostazy błony śluzowej jelit. Cytokiny te atakując zdrowe tkanki indukowały przewlekły proces zapalny charakterystyczny dla NChZJ.

\section{PIŚMIENNICTWO}

1. Kamińska B, Lewandowski P (2009) Rola wybranych czynników środowiskowych $w$ etiopatogenezie nieswoistych zapaleń jelit. Forum Medycyny Rodzinnej 3: 42-48

2. Virta LJ, Saarinen MM, Kolho KL (2017) Inflammatory bowel disease incidence is on the continuous rise among all pediatric patients except for the very young - a nationwide registry-based study on 28-year follow-up. J Crohns Colitis 11: 150-156

3. Strisciuglio C, Giugliano FP, Martinelli M, Cenni S, Greco L, Staiano A, Miele E (2016) Impact of Environmental and Familial Factors in a Cohort of Pediatric Patients with Inflammatory Bowel Disease. J Pediatr Gastroenterol Nutr 64: 569-574

4. Kinnucan JA, Rubin DT, Ali T (2013) The relevance of sleep in inflammatory bowel disease (IBD), a chronic immune-mediated inflammatory disease of the gastrointestinal tract, has recently received more attention. Gastroenterol Hepatol (NY) 11: 718-27

5. Ruemmele FM (2016) Role of Diet in Inflammatory Bowel Disease. Ann Nutr Metab 68 Suppl 1: 33-41

6. Hou JK, Abraham B, El-Serag H (2011) Dietary intake and risk of developing inflammatory bowel disease: a systematic review of the literature. Am J Gastroenterol 106: 563-573

7. Ananthakrishnan AN, Khalili H, Konijeti GG, Higuchi LM, de Silva P, Fuchs CS, et al. (2014) Long-term intake of dietary fat and risk of ulcerative colitis and Crohn's disease. Gut 63: 776-784

8. Burisch J, Pedersen N, Cukovic-Cavka S, Turk N, Kaimakliotis I, Duricova D, et al. (2014) Environmental factors in a population-based inception cohort of inflammatory bowel disease patients in Europe-an ECCO-EpiCom study. J Crohns Colitis 8: 607-616

9. Amre DK, D'Souza S, Morgan K, Seidman G, Lambrette P, Grimard G, et al. (2007) Imbalances in dietary consumption of fatty acids, vegetables, and fruits are associated with risk for Crohn's disease in children. Am J Gastroenterol 102: 2016-2025

10. Lee JY, Zhao L, Youn HS, Weatherill AR, Tapping R, Feng L, et al. (2004) Saturated fatty acid activates but polyunsaturated fatty acid inhibits Toll-like receptor 2 dimerized with Toll-like receptor 6 or 1. J Biol Chem 279: 16971-16979

11. Devkota S and Chang EB (2015) Interactions between Diet, Bile Acid Metabolism, Gut Microbiota, and Inflammatory Bowel Diseases. Dig Dis 33: 351-356

12. Geerling BJ, Dagnelie PC, Badart-Smook A, Russel MG, Stockbrugger RW, Brummer RJ (2000) Diet as a risk factor for the development of ulcerative colitis. Am J Gastroenterol 95: 1008-1013

13. Brotherton CS, Martin CA, Długi MD, Kappelman MD, Sandler RS (2016) Avoidance of Fiber Is Associated With Greater Risk of Crohn's Disease Flare in a 6-Month Period. Clin Gastroenterol Hepatol 14: 1130-6

14. Owczarek D, Rodacki T, Domagała-Rodacka R, Cibor D, Mach T (2016) Diet and nutritional factors in inflammatory bowel diseases. World J Gastroenterol 22: 895-905

15. Woting A, Blaut M ( 2016) The intestinal microbiota in metabolic disease. Nutrients 8(04): 202 
16. Kozłowska L (2010) Rola błonnika pokarmowego w utrzymaniu prawidłowej pracy jelit. Żywność dla zdrowia nr 13: 23-27

17. Furusawa Y, Obata Y, Fukuda S et al. (2013) Commensal microbe- derived butyrate induces the differentiation of colonic regulatory T-cells. Nature 504: 446-50

18. Szilagyi A, Galiatsatos P, Xue X (2016) Systematic review and meta analisis of lactose digestion, its impact on intolerance and nutritionaleffect of dairy foodrestriction in inflammatory bowel diseases. Nutr J 15: 67

19. Frigstad SO, Høivik M, Jahnsen J, Dahl SR, Cvancarova M, Grimstad $\mathrm{T}$ et al. (2016) Vitamin D deficiency in inflammatory bowel disease: Prevalence and predictors in a Norwegian outpatient population. Scand J Gastroenterol 7: 1-21

20. Elimrani I, Koenekoop J, Dionne S, Marcil V, Delvin E, Levy E, Seidman EG (2017) Vitamin D Reduces Colitis- and Inflammation-Associated Colorectal Cancer in Mice Independent of NOD2. Nutr Cancer 69(2): 276-288

21. Zhu T, Liu TJ, Shi YY, Zhao Q (2015) Vitamin D/VDR signaling pathway ameliorates 2,4,6-trinitrobenzene sulfonic acid-induced colitis by inhibiting intestinal epithelial apoptosis. Int J Mol Med 35: 1213-1238

22. Chen Y, Du J, Zhang Z, Liu T, Shi Y, Ge X, et al. (2014) MicroRNA-346 mediates tumor necrosis factor a-induced downregulation of gut epithelial vitamin D receptor in inflammatory bowel diseases. Inflamm Bowel Dis 20: 1910-8

23. Sharifi A, Hosseinzadeh-Attar MJ, Vahedi H, Nedjat S (2016) A randomized controlled trial on the effect of vitamin D3 on inflammation and cathelicidin gene expression in ulcerative colitis patients. Saudi J Gastroenterol 22: 316-23

24. Damas OM, Garces L, Abreu MT (2019) Diet as Adjunctive Treatment for Inflammatory Bowel Disease: Review and Update of the Latest Literature. Curr Treat Options Gastroenterol 17(2): 313-325

25. Cohen SA, Gold BD, Oliva S, et al. (2014) Clinical and mucosal improvement with specific carbohydrate diet in pediatric Crohn disease. J Pediatr Gastroenterol Nutr 59: 516-521

26. Obih C, Wahbeh G, Lee D, et al. (2016) Specific carbohydrate diet for pediatric inflammatory bowel disease in clinical practice within an academic IBD center. Nutrition 32: 418-425

27. Suskind DL, Cohen SA, Brittnacher MJ, et al.(2018) Clinical and fecal microbial changes with diet therapy in active inflammatory bowel disease. J Clin Gastroenterol 52: 155-163

28. Nazarenkov N, Seeger K, Beeken L, Ananthakrishnan AN, Khalili H, Lewis JD, Konijeti GG(2019) Implementing Dietary Modifications and Assessing Nutritional Adequacy of Diets for Inflammatory Bowel Disease. Gastroenterol Hepatol (N Y) 15(3): 133-144

29. Chandrasekaran A, Groven S, Lewis JD, Levy SS, Diamant C, Singh E, Konijeti GG (2019) An Autoimmune Protocol Diet Improves Patient-Reported Quality of Life in Inflammatory Bowel Disease. Crohns Colitis 360 1(3) doi: 10.1093/crocol/otz019.

30. Kruis W, Phuong Nguyen G (2016) Iron Deficiency, Zinc, Magnesium, Vitamin Deficiencies in Crohn's Disease: Substitute or Not? Dig Dis 34: 105-111

31. Kodama H, Tanaka M, Naito Y, Katayama K, Moriyama M (2020) Japan's Practical Guidelines for Zinc Deficiency with a Particular Focus on Taste Disorders, Inflammatory Bowel Disease, and Liver Cirrhosis. Int J Mol Sci 21(8): 2941

32. Ojuawo A, Keith L (2002) The serum concentrations of zinc, copper and selenium in children with inflammatory bowel disease. Cent Afr J Med 48: 116-9

33. Meng Z, Zhang B, Bai J, Geng H, Liu C (2003) Oxidative damage of sulfur dioxide inhalation on stomachs and intestines of mice. Inhal Toxicol 15(4): 397-410

34. Werner T, Hoermannsperger G, Schuemann K, Hoelzlwimmer G, Tsuji S, Haller D (2009) Intestinal epithelial cell proteome from wild-type and TNF Delta ARE/WT mice: effect of iron on the development of chronic ileitis. J Proteome Res 8(7): 3252-64

35. Constante M, Fragoso G, Calvé A, Samba-Mondonga M, Santos MM (2017) Dietary Heme Induces Gut Dysbiosis, Aggravates Colitis, and
Potentiates the Development of Adenomas in Mice. Front Microbiol 8: 1809

36. Qin X (2012) Etiology of inflammatory bowel disease: a unified hypothesis. World J Gastroenterol 18(15): 1708-22

37. Bueno-Hernández N, Vázquez-Frías R, Abreu Y Abreu AT, Almeda-Valdés P, Barajas-Nava LA, Carmona-Sánchez RI, et al. (2019) Review of the scientific evidence and technical opinion on noncaloric sweetener consumption in gastrointestinal diseases. Rev Gastroenterol Mex 84(4): 492-510

38. Joachim G (1999) The relationship between habits of food consumption and reported reactions to food in people with inflammatory bowel disease--testing the limits. Nutr Health 13(2): 69-83

39. Martino JV, Van Limbergen J, Cahill LE (2017) The Role of Carrageenan and Carboxymethylcellulose in the Development of Intestinal Inflammation. Front Pediatr 5: 96

40. Chassaing B, Van de Wiele T, De Bodt J, Marzorati M, Gewirtz AT(2017) Dietary emulsifiers directly alter human microbiota composition and gene expression ex vivo potentiating intestinal inflammation. Gut 66: 1414-1427

41. Lewis JD, Abreu MT (2017) Diet as a Trigger or Therapy for Inflammatory Bowel Diseases. Gastroenterology 152: 398-414

42. Nazarenkov N, Seeger K, Beeken L, Ananthakrishnan AN, Khalili H, Lewis JD, Konijeti GG (2019) Implementing Dietary Modifications and Assessing Nutritional Adequacy of Diets for Inflammatory Bowel Disease. Gastroenterol Hepatol (N Y) 15(3): 133-144

43. Swidsinski A, Loening-Baucke V, Herber A (2009) Mucosal flora in Crohn's disease and ulcerative colitis - an overview. J Physiol Pharmacol Suppl 6: 61-71

44. Hildebrand H, Malmborg P, Askling J, Ekbom A and Montgomery SM (2008) Early-life exposures associated with antibiotic use and risk of subsequent Crohn's disease. Scand J Gastroenterol 43: 961-966

45. Rogler G, Zeitz J, Biedermann L (2016) The Search for Causative Environmental Factors in Inflammatory Bowel Disease. Dig Dis 34 Suppl 1: 48-55

46. Felder JB, Korelitz BI, Rajapakse R, Schwarz S, Horatagis AP and Gleim G (2000) Effects of nonsteroidal antiinflammatory drugs on inflammatory bowel disease: a case-control study. Am J Gastroenterol 95: 1949-1954

47. Khalili H, Higuchi LM, Ananthakrishnan AN, Richter JM, Feskanich D, Fuchs CS, Chan AT (2013) Oral contraceptives, reproductive factors and risk of inflammatory bowel disease. Gut 62(8): 1153-1159

48. Cornish JA1, Tan E, Simillis C, Clark SK, Teare J, Tekkis PP (2008) The risk of oral contraceptives in the etiology of inflammatory bowel disease: a meta-analysis. Am J Gastroenterol 103(9): 2394-400

49. García Rodríguez LA, González-Pérez A, Johansson S, Wallander MA (2005) Risk factors for inflammatory bowel disease in the general population. Aliment Pharmacol Ther 22(4): 309-15

50. Gearry RB (2016) IBD and Environment: Are There Differences between East and West Dig Dis 34: 84-89

51. Higuchi LM, Khalili H, Chan AT, Richter JM, Bousvaros A and Fuchs CS (2012) A prospective study of cigarette smoking and the risk of inflammatory bowel disease in women. Am J Gastroenterol 107: 13991406

52. Calkins BM (1989) A meta-analysis of the role of smoking in inflammatory bowel disease. Dig Dis Sci 34: 1841-1854

53. Rubin DT, Hanauer SB (2000) Smoking and inflammatory bowel disease. Eur J Gastroenterol Hepatol 12: 855-862

54. Guo AY, Stevens BW, Wilson RG, Russell CN, Cohen MA, Sturgeon HC et al. (2014) Early life environment and natural history of inflammatory bowel diseases. BMC Gastroenterol 14: 216

55. Aratari A, Margagnoni G, Feigush L, Koch M, Papi C (2014) Environmental factors. and clinical course of inflammatory bowel disease: which evidences? Recenti Prog Med 105(12)

56. Rozich JJ, Holmer A, Singh S (2020) Effect of Lifestyle Factors on Outcomes in Patients With Inflammatory Bowel Diseases. Am J Gastroenterol doi: 10.14309/ajg.0000000000000608 Epub ahead of print] 
57. Martin TD, Chan SS, Hart AR (2015) Environmental factors in the relapse and recurrence of inflammatory bowel disease: a review of the literature. Dig Dis Sci. 60(5): 1396-405

58. Beamish LA, Osornio-Vargas AR, Wine E (2011) Air pollution: An environmental factor contributing to intestinal disease. J Crohns Colitis 5(4): 279-86

59. Ananthakrishnan AN, Bernstein CN, Iliopoulos D, Macpherson A, Neurath MF, Ali RAR, et all. (2018) Environmental triggers in IBD: a review of progress and evidence. Nat Rev Gastroenterol Hepatol 15(1): 39-49

60. Salim SY, Kaplan GG, Madsen KL (2014) Air pollution effects on the gut microbiota: a link between exposure and inflammatory disease. Gut Microbes 5(2): 215-219

61. Legaki E, Gazouli M (2016) Influence of environmental factors in the development of inflammatory bowel diseases. World J Gastrointest Pharmacol Ther 7: 112-125
62. Jin Y, Wu S, Zeng Z, Fu Z(2017) Effects of environmental pollutants on gut microbiota. Environ Pollut 222: 1-9

63. Zhang W, Guo R, Yang Y, Ding J, Zhang Y (2016) Long-term effect of heavy-metal pollution on diversity of gastrointestinal microbial community of Bufo raddei. Toxicol Lett 258: 192-197

64. Wu J, Wen XW, Faulk C, Boehnke K, Zhang H, Dolinoy DC, et al. (2016) Perinatal Lead Exposure Alters Gut Microbiota Composition and Results in Sex-specific Bodyweight Increases in Adult Mice. Toxicol Sci 151: 324-33

65. Martin TD, Chan SS, Hart AR (2015) Environmental factors in the relapse and recurrence of inflammatory bowel disease: a review of the literature. Dig Dis Sci 60: 1396-405

66. Matsuoka K, Kanai T (2015) The gut microbiota and inflammatory bowel disease. Semin Immunopathol 37: 47-55

\section{Environmental factors increasing the risk of activation and development of inflammatory bowel diseases}

\section{Jerzy Mrowicki ${ }^{\natural}$, Małgorzata Mrowicka , Ireneusz Majsterek}

Department of Clinical Chemistry and Biochemistry, Medical University of Lodz, Łódź

${ }^{\circledR}$ Corresponding author: jerzy.mrowicki@umed.lodz.pl

Keywords: Inflammatory bowel disease; ulcerative colitis; Crohn's disease CD; environmental factors; intestinal epithelial cells

\section{ABSTRACT}

Inflammatory bowel disease (IBD) is a particularly troublesome disease that has a huge impact on the human digestive tract, mainly the intestine. These diseases manifest themselves as chronic, uncontrolled inflammation of the intestines, difficult to control, with periods of spontaneous exacerbations and remissions. Depending on the variety of symptoms present and their location in the human gastrointestinal tract, these diseases can occur in various forms. The most common: ulcerative colitis (UC) and Crohn's disease (CD). The underlying cause of activation as well as subsequent development is not clearly defined, but it is known that these disorders are autoimmune. The pathogenesis of IBD is associated with chronic idiopathic, recurrent gastrointestinal inflammation. Exposure to many environmental factors, which are partially discussed in the following work, especially in people genetically predisposed to the development of these diseases, can activate the chronic inflammatory process of the intestine. 